\title{
IMPLEMENTASI SUFI HEALING PADA ERA NEW NORMAL PANDEMI COVID-19 DALAM MENJAGA KONDISI HOMEOSTASIS TUBUH MASYARAKAT
}

(Studi Analisis di Desa Kayen Bandarkedungmulyo Jombang Jawa Timur)

\author{
Muhammad Asrori Ma'sum \\ Institut Agama Islam Bani Fattah Jombang \\ muhammadasrorima225@gmail.com \\ Muhammad Nasrul Waton \\ Institut Agama Islam Bani Fattah Jombang \\ muhammadnasrulwaton@iaibafa.ac.id
}

\begin{abstract}
This article discusses the use of Sufi healing in the new normal era of the Covid-19 pandemic in maintaining the homeostatic condition of the community in Kayen Village, Bandarkedungmulyo Jombang, East Java. Sufi healing can be interpreted as a model of alternative therapy or physical or psychological healing based on values and adopting the practice of Sufism as a means of healing or prevention. Meanwhile, the body's efforts to maintain a stable state of the environment are called Homeostasis which is taken from Greek, namely homeo which means the same and stasis which means maintaining a state which means staying in a healthy condition. With worship activities adapted from the practices of Sufism, carried out by the community in Kayen Village during the new normal Covid-19 pandemic, such as reading the Koran, dhikr, praying, reading prayers that bring calm, increasing one's faith and piety so that it raises relaxation


response which has an impact on increasing body immunity. By increasing one's body immunity, it keeps people from disease, viruses, bacteria, or other pathogens, so that a person can maintain a healthy body condition (homeostasis). Although healing requires istiqomahan in carrying out worship practices carried out by someone.

Keywords: Sufi Healing, New Normal, Homeostasis

\section{Pendahuluan}

Manusia adalah makhluk biologis, sosial, dan spiritual. Sebagai makhluk biologis, manusia terdiri atas sel-sel yang membentuk organorgan yang akan berkembang dengan ciri-ciri tertentu. Sebagai makhluk social, manusia sangat terikat dan berinteraksi langsung-tidak langsung dengan makhluk lainnya. Sedangkan manusia sebagai makhluk spiritual, manusia tidak hanya berhubungan dengan orang lain dalam sistem masyarakat atau dunia yang kasap mata, tetapi juga berhubungan dengan Sang Pencipta. Membicarakan nilai spiritualitas bukanlah hal sederhana, melainkan hal yang sangat rumit, baik secara ilmiah maupun implementasinya. Manusia hanya mampu membuktikan dengan gejalagejalanya saja sebagai menjadi tolak ukurnya. ${ }^{1}$

Islam sendiri adalah agama rabmatan li al-alamin, agama yang membuat penganutnya terhindar dari marabahaya. Di dalam ajaran agama Islam terdapat nilai-nilai agar umatnya terus beribadah kepada Allah, kapanpun dan dimanapun. Untuk terus mampu beribadah kepada Allah dibutuhkan fisik dan jasmani yang sehat dan kuat. Oleh karena itu, persoalan kesehatan dan menjaga kesehatan penting dalam ajaran islam. Terganggunya persoalan kesehatan membuat seseorang tidak maksimal menjalankan ibadahnya.

Dalam proses kehidupan, manusia akan selalu berhadapan dengan perubahan, baik perubahan yang terjadi di dalam dirinya sendiri maupun perubahan yang terjadi di luar dirinya. Semua perubahan tersebut dapat menimbulkan kebaikan, keburukan, kekuatan maupun tekanan.

Apalagi pada kondisi sekarang ini, adanya virus corona yang sedang mewabah di seluruh belahan dunia. Tak terkecuali di Indonesia, Corona virus pertama kali dilaporkan di Indonesia pada tanggal 2 Maret 2020 dengan dua kasus. Data 31 Maret menunjukkan bahwa corona virus

\footnotetext{
${ }^{1}$ Mahbub Junaidi,. 'Manusia Dalam Berbagai Perspektif', (Dar el-Ilmi: jurnal studi agama, pendidikan dan humaniora, Vol 4 No 1, April 2017), h. 50
} 
semakain menyebar dengan jumlah kasus 1528 dan 136 kematian. $^{2}$ Studi di singapura menunjukkan pencemaran di kamar mandi atau toilet pasien COVID-19 dengan gejala ringan. Virus dapat dideteksi di gagang pintu, dudukan toilet, jendela, lemari, hingga kipas ventilasi, namun tidak pada sempel udara. ${ }^{3}$ Manusia yang memiliki daya tahan tubuhnya lemah atau imuitasnya menurun lebih mudah terkena virus ini, begitu juga sebaliknya.

Virus corona menginfeksi manusia dapat menimbulkan suatu gejala dari yang mulai ringan, sedang, dan berat. Bentuk gejala utama yang muncul ketika virus corona ini menginfeksi manusis adalah demam (38 C). Kesulitan bernafas dan batuk. Selain dari gejala-gejala tersebut, dapat disertai sesak memberat, gejala gastrointestinal seperti gejala saluran nafas dan diare, serta fatigue. ${ }^{4}$

Oleh sebab itulah masyarakat harus berhati-hati dan perlu melindungi diri masing-masing. Karena kita tidak tau virus itu tempatnya ada dimana oleh sebab itu kita harus waspada dan mematuhi protokol kesehatan yang telah dihimbau oleh pemerintah. Protokol kesehatan yang jika anda merasa tidak sehat dengan gejala seperti yang telah dijelaskan diatas beristirahat yang cukup apaabila disertai dengan kesulitan bernafas (sesak atau nafas cepat), segera berobat ke fasilitas pelayanan kesehatan. Dengan ketentuan menggunakan masker, apabila batuk dan bersin gunakan etika yang benar, usahakan tidak menggunakan fasilitas umum. ${ }^{5}$

Masa New Normal seperti sekarang ini merupakan tatanan baru yang harus dilakukan oleh setiap orang. Meskipun masyarakat harus beradaptasi dengan kondisi sekarang ini. Masyarakat terkadang kurang mematuhi protokol kesehatan yang dihimbau oleh pemerintah desa meskipun masyarakat tahu ketika keluar rumah misalnya dihimbau untuk memakai masker tetapi tidak dilakukan. Meskipun pemerintah desa sudah melakukan sosialisasi juga. Walaupun masyarakatnya tidak ada yang terkena virus corona. Perlu adanya usaha dalam menjaga agar kondisi tubuh tetap seimbang. Oleh karena itu penulis tertarik untuk membahas Sufi Healing untuk dapat dimanfaatkan dalam menjaga kondisi tubuh tetap seimbang (homeostasis) pada masyarakat di desa Kayen Bandarkedungmulyo Jombang Jawa Timur.

\footnotetext{
2 Adityo Susilo,, dkk. "Corona Virus Diseases (COVID-19): tinjauan literatur terkini Corona Virus Diseases 2019: review of current literatures", (jurnal penyakit dalam Indonesia, Vol 7 No 1, Maret 2020), h. 46

${ }^{3}$ Ibid, Adityo Susilo,, dkk, h. 47

${ }^{4}$ Yuliana. Corona Virus Diseases (COVID-19): sebuab tinjauan literatur. wellness and healthy magazine, 2020), h. 188-189

${ }^{5}$ https://www.kemkes.go.id, diakses 29 Mei 2020
} 


\section{Sufi Healing}

Sufi healing berasal dari dua kata yaitu sufi dan healing. Sufi adalah orang yang istiqomah bersama Allah, berprilaku baik dengan manusia, dan bergaul dengan bijaksana. Istiqomah adalah menghiraukan kesenangan dirimu atas perintah Allah. Berprilaku baik dengan manusia maksudnya jika dirimu tidak menginginkan orang lain sesuai dengan dirimu, bahkan hatimu mau mengikuti orang lain asal tidak keluar dari syari'at. ${ }^{6}$ Mudahnya sufi adalah orang yang selalu berhubungan dengan Allah, dan selalu mendekat dengan Allah. Sedangkan healing dari kata heal yang memiliki empat arti, yaitu: membuat sempurna atau utuh, bebas dari penyakit, memulihkan kesehatan. Kedua, menuju suatu akhir atau konklusi (misalnya terjadi koflik perorangan, kelompok, yang akhirnya terjadi pemulihan dari koflik tersebut). Ketiga, membersihkan, bebas dari sifat buruk, memurnikan. Keempat, dampak suatu obat. Healing adalah suatu penyembuhan baik penyakit fisik maupun penyakit psikis.

Berdasarkan pengertian diatas sufi healing bisa diartikan sebagai model terapi alternatif atau penyembuhan fisik atau psikis yang didasarkan pada nilai-nilai dan mengambil praktik tasawuf sebagai sarana penyembuhan atau pencegahan. ${ }^{8}$ Terapi ini sudah dikenal cukup lama sejak islam dan tasawuf berkembang. Tapi ada yang mengelompokkan kedalam ranah psikologi secara rujukan ilmiah. Dalam ilmu kedokteran juga dikenal dengan istilah psikoneuroimunologi, yang menyatakan ada keterkaitan antara fikiran dan tubuh. Oleh karena itu ada yang mengistilahkan bahwa timbulnya penyakit itu berasal dari fikiran. ${ }^{9}$ (Yang sebenarnya tubuh, fikiran, jiwa memiliki hubungan. Bagi kaum sufi penyaluran daya penyembuhan tidak sama, mereka dapat melakukan sesuai dengan pengalaman mereka masing-masing saat dalam penemuan diri. Terkadang terjadi begitu saja tanpa direncana dan tanpa unsur kesengajaan. ${ }^{10}$

Para salik juga merasakan bahwa sufi healing telah dijalani saat mereka melakukan suatu tahapan al-bidayah (permulaan), yaitu ada beberapa tahapan kesufian yang mereka masuki, yakni takhalli (pengosongan dari sifat-sifat yang merusak, seperti ujub, riya', sombong,

\footnotetext{
${ }^{6}$ Al-Ghozali. Rahasia Ilmu Nafi': Kilas Balik. Menuju Ilmu Nafi', alih bahasa Abu Fahdinal Husna dari judul asli Ayyuhal Walad, (Jombang: Daru-Hikmah, 2005), h.30

7 Amin Syukur,. Sufi Healing Terapi Dengan Metode Tasawuf, (Jakarta: Erlangga, 2012), h. 13

${ }^{8}$ Omar Ali-shah,. Tasawnf Sebagai Terapi, (Bandung: Pustaka Hidayah, 2002), h. 17

9 Amin Syukur,. Sufi Healing: Terapi Dalam Literature Tasawuf', (Walisongo, Vol 20 No 2, November 2012), h. 71

10 Sulaiman. Sufi Healing: Penyembuhan Penyakit Labiriab dan Batiniah, (Semarang: karya abadi jaya, 2015), h. 4
} 
takakbur, dan lain-lainnya). Kemudian tahapan berikutnya adalah tahalli (mengisi jiwa dengan sifat-sifat yang mulia lagi baik, seperti tawakkal, zuhud, sabar, syukur, Dan lain-lainnya). Tahapan ketiga adalah tajalli (penemuan dari segala apa yang telah dilakukan dan memerapkan pada kehidupannya sehari-hari). Selanjutnya ada riyadah dan mujahadah, melewati maqamat dan abwal. Lalu sampai pada nibayah (puncak pencapaian). Sufi mengatakan bahwa nihayah ini merupakan maqam terakhir, yaitu wushul (sampai/pencapaian). Ihsan (perbuatan baik), atau fana' (ketidakkekalan), orang yang telah sampai pada kedudukan ini disebut dengan abl al-irfan. ${ }^{11}$

Maqomat adalah jamak dari kata maqam. Secara bahasa memiliki arti pangkat atau derajat. Sedangkan secara istilah, maqam memiliki arti kedudukan spiritual. Dari sisi bahasa Ingris maqamat disebut dengan stations atau stage. Menurut disiplin ilmu Tasawuf maqamat adalah suatu kedudukan yang dimiliki oleh seorang salik dihadapan Allah, yang didapat dengan riyadoh dan mujahadah serta hubungan yang tiada putus dengan Allah. ${ }^{12}$ Menurut Al Ghazali (w. 1111) maqamat dan ahwal adalah berbeda, maqamat bersifat tetap sedangkan abwal memiliki sifat berubahubah. Untuk memberi contoh Al-Ghozali menganalogikan dengan warna kuning yang mempunyai dua bagian. Warna kuning akan tetap pada emas, sedangkan warna kuning tidak akan tetap pada orang yang menderita penyakit kuning. ${ }^{13}$ Menurut Harun Nasution abwal adalah keadaan mental seseorang, seperti senang, sedih, takut dan sebagainya. Abwal bertolak belakang dengan maqamat tetapi abwal selalu mengiringi maqamat, karena ahwal bukan didapat dengan usaha yang keras melainkan atas anugrah dari Allah dan sifatnya sementara bisa hilang kapanpun. ${ }^{14}$

Berikut ini maqamat yang disusun oleh Ibnu Atha'ilah dalam salah satu kitab beliau at-Tanwir fi isqath at-Tadbir, sebagai berikut:

At-Taubat (taubat)

Taubat merupakan kedudukan pertama dan yang paling awal dilalui oleh seorang sufi dalam tujuannya menuju Allah SWT. Mengenai taubat banyak definisi yang dibertikan oleh para sufi seperti Al-Junaid mendefinisikan usaha untuk tidak berbuat dosa yang lalu pada masa sekarang. Seorang sufi lainnya, syekh Sahal menyatakan bahwa hendaklah seseorang itu ingat perbuatan dosa yang telah lalu dan memberikan dan

\footnotetext{
${ }^{11}$ Ibid, Amin Syukur, 72

12 Syamudin Ni'am,. Tasawuf Studies: Pengantar Belajar Tasawnf, (Yogyakarta: Ar-ruz Media, 2014), h. 137

${ }^{13}$ Ibnu Farhan,. "Konsep Maqamat Dan Ahwal Prespektif Para Sufi", (YAQZHAN, Vol 2 No 2, Desember 2016), h. 162

${ }^{14}$ Nata, Abuddin. Akblaq Tasawuf, (Jakarta: PT Raja Grafindo Persada, 2012), h. 204
} 
berupaya membersihkan hati dari suatu bisikan-bisikan yang mengarah pada perbuatan dosa. Taubat pada intinya adalah meyerahkan atau mengakui segala sesuatu berupa kesalahan yang pernah dilakukan pada masa lalu untuk selalu istiqomah melakukan apa yang telah diperintahkan dan menjahui apa yang telah dilarang Allah SWT.

Ibnu Atha'illah menjelaskan bahwa seorang sufi dalam maqom tobat haruslah kembali kepada Allah SWT dari semua perbuatan yang tidak diridhoi ke jalan yang dirodhoi-Nya. Berpasrah diri dan fokus dengan kewajiban yang telah diberikan oleh Allah SWT kepada seorang manusia. Az-Zubd (zuhud)

Zuhud juga merupakan maqom yang penting juga oleh seorang sufi dalam perjalanannya menuju Allah SWT. Beberapa definisi yang diberikan oleh para sufi diantaranya oleh Imam Ali bahwa zuhud ialah haruslah tidak terpengaruh dan iri hati terhadap orang-orang yang keduniawian meskipun itu dari orang kafir ataupun orang mu'min. Sedangkan dari Al-Junaid menyatakan bahwa zuhud adlah suka memberi sampai tidak adan yang dimilikinya dan tidak serakah.

Ibnu Atha'illah membagi zuhud dalam dua tahapan, zuhud batin yang samar dan zuhud lahir yang jelas. Penerapannya dari kedua konsep zuhud adalah ketika seseorang melakukan zuhud yang lahir, maka haruslah tidak berlebihan kepada barang yang halal, baik berupa pakaian, makanan, dan lain sebagainya. Sedangkan zuhud batin adalah ketika seseorang tidak membenarkan perasaan hati yang muncul seperti perasaan sombong terhadap orang lain, syirik, iri dengki, senang dipuji dan lain sebagainya.

As-Sabr (sabar)

Sabar menurut al-Kalabadzi sebagai harapan seorang hamba terhadapa kebahagiaan kepada Allah SWT. Sabar adalah jalan menuju kebahagiaan tetapi juga memerlukan suatu bentuk upaya yang sangat keras dan pantang menyerah serta memerlukan waktu yang panjang. Menurut Ibnu Atha'illah sabar adalah selalu berusaha menjauhi dari perbuatan-perbuatan yang tidak disukai oleh Allah, didalamnya ada sikap mengatur terdapat sesuatu yang telah diatur oleh Allah. Sabar menurut Ibnu Atha'ilah ada beberapa macam, sabar terhadap yang wajib, sabar terhadap pengaturan dan pilihan serta sabar terhadap yang dilarang.

As-Synkur (syukur)

Menurut al-Muhasibi syukur adalah kelebihan-kelebihan dari Allah SW'T, kepada seseorang karena bentuk rasa terimakasih atas nikmat yang telah diberikan oleh Allah. Dengan demikian ketika seseorang bersyukur 
atas nikmat yang telah diberikan oleh Allah maka akan ditambah dengan nikmat yang lebih besar.

Ibnu Atha'illah menjelaskan apa itu syukur, beliau mengutip dari al-Junaid mengenai syukur. Al-Junaid mengatakan syukur adalah ketika seseorang tidak melakukan ma'siat melalui nikmat yang telah diberikan oleh Allah. Oleh karena itu seseorang pada maqom syukur menggunakan semua nikmat yang telah diberikan untuk segala aktivitas atas perintah Allah SWT.

Al-khauf dan Ar-Raja' (rasa tajut dan rasa berharap)

Rasa takut kepada Allah akan selalu membuat orang melakukan kewajibannya dan menjahui apa yang telah dilarang. Sedangkan raja' adalah ketika orang berharap atas semua kebutuhannya kepada Allah. Rasa taku dan rasa berharap merupakan dua sikap yang saling terpaut satu sama lain dan tidak dapat dipisahkan. Syekh Sahl mengibaratkan rasa takut itu ibarat seorang laki-laki dan rasa berharap itu adalah ibarat seorang perempuan, maka keduanya haruslah saling berjalan beriringan sampai nanti akan melahirkan sebuah hakikat iman.

Menurut Ibnu Atha'illah, jika seseorang berada pada kedudukan khauf maka orang tersebut akan selalu melaksanankan perintah Allah SWT dan takut jika tidak mengerjakannya. Sedangkan orang yang berada pada kedudukan raja' semua aktivitassnya akan diliputi suka cita dan selalu disibukkan hubungannya dengan Allah SWT.

At-Tawakkal (berserah diri)

Al Junaid menatakan bahwa hakikat tawakkal ialah ada dan tidak adanya sesuatu itu karana semata-mata kehendak dan kekuasaan Allah, dan karena Allah sesuatu menjadi ada. Sedangkan Ibnu Atha'illah memberikan sebuah definisi mengenai tawakkal yaitu sikap seseorang dimana ia menyerahhkan sepenuhnya kendali kepada Allah dan bersandar segala urusan kepada-Nya.

Al-Hubb (cinta)

Ada bebeapa sufi yang memasukkan maqom cinta kedalam hal (keadaan), namun di sini Ibnu Atha'illah memasukkan cinta kedalam maqomat. Dalam maqom cinta ini seseorang akan memilih segala sesuatunya sesuai dengan pilihan kekasihnya. Dengan demikian akan menerima aturan yang ditetapkan oleh Allah dan menjauhi apa yang tidak disukai oleh Allah. Seseorang akan merasakan keskosongan dari segala apapun kecuali Allah SWT.

\section{Ar-Ridha}

Menurut Syekh Zunnun al Misri mengatakan bahwa ridha adalah suatu keadaan hati dimana dirinya merassa bahagia atas apa yang telah 
ditetapkan oleh Allah SWT. Sedangkan menurut Ibnu Atha'illah, maqom ridho adalah sikap ikut campur seseorang terhadap kehendak Allah. Intinya merasa cukup dan menerima dengan apa yang telah diatur oleh Allah. Maqom ridha merupakan kedudukan yang paling tinggi menurut pandangan Ibnu Atha'illah. ${ }^{15}$

Ada bebarapa mengenai ahwal yang dikenal oleh para sufi dalam perjalanannya menuju Allah. Berikut ahwal yang sering dijumpai oleh para sufi sebagai berikut:

\section{Al-Muhasabah dan Al-Muroqobah (waspada dan mawas diri)}

Waspada adalah yakin bahwa Allah mengetahui segala apa yang ada di fikiran, perbuatan dan apa yang ada di hati. Dengan begitu seseorang akan memepertimbangkan prilakunya karna sadar Allah mengetahui apa yang telah dilakukan. Sedangkan mawas diri adalah mencermati semua perbuatan sehari-hari apakah sudah sesuai dengan apa yang diperintahkan oleh Allah.

Al-Isyq (rindu)

Kerinduan merupakan sebuah wujud adanya cinta kepada Allah yang mengakibatkan seorang sufi ingin selalu bersama dengan berbagai media ibadah. Bahkan saking rindunya seorang sufi kepada Allah, kematian menjadi penghalang akan pertemuan dirinya dengan Allah.

Al-Uns (intim)

Dalam pandangan kaum sufi keintiman merupakan sikap merasa saling berteman dan tak pernah merasa sepi. Merasa sepi disaat ramai, merasa ramai disaat sepi. Ia adalah orang yang selalu memikirkan kekasihnya karena dimabuk cinta. Sedangkan ketika merasa berteman, karena merasa dalam pemeliharaan Allah.

Dari semua Maqomat dan ahwal, ketika para sufi telah sampai pada maqam wushul pencapaian), ibsan (perbuatan yang baik), ataupun fana' (ketidakkekalan) ini akan mengalami healing dengan sendirinya. Nah bagaimana dengan orang awam untuk melakukan healing sufistik. Jalan yang bisa dilakukan sebenarnya sama dengan apa yang telah dilakukan kaum sufi, yaitu seoerti berdzikir, sholat, membaca sholawat, dan mendengarkan musik. ${ }^{16}$

Berbagai cara yang telah disebutkan diatas bisa memiliki dampak yang positif dalam penyembuhan penyakit tentu itu semua melalui suatu perantara atau bimbingan dari seorang guru ataupun terapis. Latihanlatihan yang dilakukan untuk memperoleh suatu energi yang stabil,

${ }^{15}$ Ibid, Farhan, h. 164-169

${ }^{16}$ Ibid, Amin Syukur, h. 72

110 Muróbbî: Jurnal Ilmu Pendidikan 
seimbang, meyatu disegala level, sehingga mendapat keseimbangan dalam diri. Penyembuhan berpusat dalam sumber kehidupan yang bertempat di hati dan hubungan spiritual. ${ }^{17}$ Spiritualitas yang dimiliki oleh seseorang sangat berhubungan dengan qalb (hati) karna hati itu merupakan pusat dari semua kegiatan jiwa. Jika hati seseorang sakit maka sakitlah kegiatan atau aktivitas kerohaniannya. ${ }^{18}$

\section{Menurut Pnina Werbner and Helene Basu:}

"the healing powers of the saint are gropunded in a belief in his ability to see below the surface, to the accult social causes of illness, the thoughts, feelings and accidental transgressions which have brought about pain, chronic illness, infertility, depression, business failures and so forth". ${ }^{19}$

Artinya kekuatan penyembuhan dari orang suci diraba-raba dalam kemampuan keyakinannya untuk melihat dasar dari permukaan, ke penyebab okultisme dan sosial dari penyakit, pikiran, perasaan dan pelanggaran yang tidak disengaja yang menyebabkan rasa sakit, penyakit kronis, infertilitas, depresi, kegagalan bisnis dan lain sebagainya. Jadi para sufi itu ketika menangani pasien dengan gejala penyakit tertentu dilihat dari keimanan seorang dan melihat perbuatan apa yang tidak sesuai aturan.

Menurut Amin Syukur, semua yang dilakukan oleh seorang sufi harus selalu didasari dengan ingat dan merasakan akan hadirnya Allah Swt. Seluruh rangkaian fase yang dilakukan oleh seorang sufi intinya terletak pada dzikir kepada Allah dengan macam-macam bentuknya dan dengan arti luas maupun arti sempit. Oleh karna itu semua kegiatan sufi healing harus dilakukan dengan penuh kesadaran melalui bimbingan dari seorang guru. ${ }^{20}$

Dikutip dari Farhat Naz Rahman menyatakan bahwa

"the Sufi approach of Theraphy Sufis have called the act of rikr, the recognition of flawlessness and the flawlessness of recognition. Chanted, moved, inbaled, in silence and in tone, ziker welcomes us to a complete attention to the living potentials inside or spirit. Reflections in the bush and with ifferent expressions of inyernal focuses is likewise central for

\footnotetext{
17 O'riordan, Linda. Seni Penyembuhan Alami: Rahasia Penyembuban Melalui Energi Ilabi, penerjemah Sulaiman al-Kumayi, (Jakarta: Gugus press, 2002), h. 50-51

${ }_{18}$ M. Sholihin, Terapi Sufistik, (Bandung: pustaka setia, 2004), h. 69

19 Farhat Naz Rahman,. "spiritual healing and sufi practices", (nova journal of sufism and spirituality, Vol, 2 No. 1, 2014), h. 7

${ }^{20}$ Ibid, Amin Syukur, h. 408
} 
Sufis and will astructure a piece of the day's practices and investigating the realm of ziker, breath, heart and insightful moving. The modification and nature of environment produced through such development and a sound practice empowers one to wind up all the more rapidly responsive to the internal planes of awareness". ${ }^{21}$

Para sufi menyebut tindakan zikir sebagai pengakuan atas ketidak sempurnaan dan ketidak sempurnaan pengakuan. Dinyayikan, digerakkan, dihirup, masuk diam dan dalam nada, zikir menyambut kita untuk perhatian penuh pada potensi hidup di dalam roh kita. Refleksi dalam keheningan dan ekpresi yang berbeda dari focus internal juga penting bagi para sufi dan akan menyusun dari sebagian praktik serta penyelidikan hari itu. Alam zikir, nafas, hati dan gerak wawasan. Modifikasi dan sifat lingkungan yang dihasilkan melalui perkembangan seperti itu dan praktik yang baik memberdayakan seseorang untuk mengakhiri segalanya semakin cepat tanggap terhadap bidang kesadaran internal.

Memang dzikir sangat melekat dengan sufi dan dzikir juga yang membedakan ibadah yang dilakukan oleh para sufi. Dzikir (theomnemie, sebutan dari Nwyia yang di pinjam dari agama Kristen Bizantium), mengingat atau mengenang tuhan. Yang dapat dilakukan baik secra diam-diam ataupun bersuara. Dzikir adalah hal yang paling kuat dan penting menuju Allah. Karena seorang sufi tak akan pernah sampai kepada Allah (wushul illa Allab) tanpa mengingatnya terus-menerus. ${ }^{22}$ Dzikir adalah satu langkah menuju jalan cinta. Ketika seseorang mincintai kekasihnya akan menyebut dan selalu mengingat kepadanya. Karena sebab itulah seorang sufi yang di dalam hatinya telah menancap cinta kepada Allah, di dalam hatinya-lah tempat dzikir yang terusmenerus. ${ }^{23}$

Dzikir ada beberapa macam yang pertama, dzikir lisan adalah menyebut nama Allah dengan bersuara dan menggunakan lidah. Kedua, Dzikir qalbi adalah menyebut nama Allah dengan hati, sehingga tidak diketahui oleh orang lain dan tetap terjaga keilkhlasannya. Ketiga dzikir aqli adalah menyebut, memikirkan makna, arti, maksud yang ada di dalam dzikir. Keempat, dzikir ruh adalah kembalinya fitrah manusia dalam wujud ke-ma'rifatannya. ${ }^{24}$

${ }^{21}$ Ibid, Rahman, h. 6

22 Anniemarie Schimmel, Dimensi Mistik Dalam Islam, penerjemah: Sapardi Djoko Damono dari judul asli Mystical of Islam, (Jakarta: Pustaka firdaus, 2003), h. 221

${ }^{23}$ Ibid, 213

${ }^{24}$ Limas Dodi,, "Nilai Spiritualitas Sayyed Hossein Nasr dalam Manajemen Pendidikan Islam”, (Dirāsāt: Jurnal Manajemen dan Pendidikan Islam, Vol 4, no. 1 2018), h. 76 
Tidak hanya dzikir saja, termasuk sholat adalah kegiatan sufistik. Sholat dalam bahasa Arab mengandung arti do'a permohonan kebajikan dan pujian, sedangkan sholat pada hakekatnya menghadap hatinya dan memunculkan rasa takut serta memunculkan rasa keagungan-Nya dan kekuasaan-Nya. Para sufi biasanya selain menjalankan sholat wajib, ia juga menjalankan sholat sunnah. Sholat sunnah para sufi dalam menjalankannya memberi tambah rokaatnya sampai dengan ratusan rokaat. Kenapa para sufi melakukan hal demikian, karena dengan begitu para sufi bisa sampai merasakan ketiadaan (fana').

Selain itu para sufi juga melakukan sholawat. Sholawat adalah suatu bentuk ucapan yang menggambarkan kasih sayang kita kepada Nabi SAW yang telah memberi jalan terang bagi kita dari Allah SW'T. Sholawat yang kita ucapkan kepada beliau, nantinya kita akan termasuk orangorang yang dilindungi dan dido'akan diakhir perjalanan hidup nantinya. Hal ini juga bisa dikatakan mendapat syafa'at dari baginda Nabi SAW. Sholawat juga merupakan bentuk dzikir.

Dari semua kegiatan yang dilakukan oleh seorang sufi seperti dzikir, membaca sholawat, dan sholat. Untuk mengolah spiritualnya para sufi juga melakukan puasa. Puasa yang dilakukan selain puasa wajib yaitu puasa sunnah. Semua puasa sunnah yang dikerjakan atas bimbingan oleh seorang guru atau Mursyid. Tak jarang juga puasa yang dikerjakan oleh seorang salik terus-menerus kecuali hari yang diharamkan puasa. Biasanya orang yang berpuasa pada siang harinya dibarengi dengan tidak tidur pada malam harinya. Hal seperti itu dilakukan oleh seorang sufi karena agar terus ingat dengan Allah, dan tetap terjaga.

Ada juga dikatakan dengan relaksasi sufi. Relaksasi atau meditasi dari bahasa latin meditation yang berarti merenungkan dan serapan dari maderi (kesehatan). Pengertian lain dari meditasi adalah pemusatan fikiran dan perasaan. Meditasi juga didefinisikan sebagai praktik berfikir secara mendalam dalam suatu keheningan dengan tujuan untuk ketenangan batin dan juga keagamaan. Jadi meditasi pada garis besarnya adalah kegiatan yang memfokuskan fikiran dan perasaan untuk ketenangan batin. ${ }^{25}$

Dapat dikatakan seperti yang telah dijelaskan diatas bahwa seperti dzikir, sholat, sholawat, puasa dan relaksasi/meditasi sufi merupakan serangkaian aktivitas ibadah yang dijalankan karena keikhlasan dan ketulusan hati serta yang paling utama adalah mengharap keridhoan dari Allah SWT. Atas izin dan ridhonyalah semua aktivitas yang kita kerjakan semua menjadi bermanfaat untuk diri sendiri dan orang lain. Ini sesuai dengan pengertian dari sufi orang yang selalu secara konsisten bersama

${ }^{25}$ Ujam Jaenudin,. Psikologi Transpersonal, (Bandung: CV. Pustaka Setia, 2012), h. 218 
Allah dan berbuat baik pada sesama. Semua itu akan membuat bertambahnya iman kita kepada Allah dan membuat kita merasa tenang.

\section{Homeostasis Tubuh}

Manusia merupakan organisme dengan multisel yang dapat mempertahankan kondisi tubuhnya dengan bebrbagai lingkungan yang berubah-ubah karena dapat mempertahankan keadaan lingkungan dalam tubuh. Dengan keadaan lingkungan dalam tubuh yang stabil manusia dapat hidup dalam lingkungan yang bervariasi. Menurut Walter Cannon seorang ahli ilmu faal dari Amerika Serikat menyatakan bahwa usaha tubuh dalam menjaga keadaan lingkungan dalam yang stabil disebut dengan Homeostasis yang diambil dari bahasa yunani yaitu homeo berarti sama dan stasis yang berarti mempertahankan keadaan. Homeostasis dipertahankan dengan proses pengaturan sistem organ tubuh melalui pengaturan keseimbangan yang bersifat halus dan dinamis. Hampir semua penyakit didasarkan pada kegagalan tubuh dalam mempertahankan homeostasisnya. ${ }^{26}$ Dapat dikatakan bahwa homeostasis adalah kondisi sehat.

\section{Letak Geografis dan Demografis Desa Kayen Bandarkedungmulyo Jombang}

Dari geografis dan demografis Desa Kayen merupakan sebuah desa yang terletak di kecamatan Bandarkedungmulyo Jombang. Letak desa Kayen adalah 15 Kilometer arah barat dari pusat kota Jombang. Desa ini memiliki 4 dusun yaitu dusun Semelo, dusun Kayen, dusun Bodeh dan dusun Tegalsari. Total jumlah penduduk adalah 7.258 jiwa, dengan perincian jumlah laki-laki 3270 jiwa dan jumlah perempuan 3988 jiwa. ${ }^{27}$ (Wawancara, Kayen, 25 Mei 2020)

\section{Prilaku Masyarakat Desa Kayen Masa New Normal Pandemi covid-19}

Prilaku adalah sebuah bentuk tanggapan dari diri pribadi terhadap suatu obyek atau benda yang ada disekitar. Contoh saja pada saat pandemi covid-19 ini banyak orang merespon atau pun nenanggap pandemi ini bermaacam-macam. ${ }^{28}$ Kondisi seperti sekarang ini dengan adanya covid sedikit banyak telah mempengaruhi orang-orang bahwa

\footnotetext{
26 Siagian, Minarma. HOMEOSTASIS: keseimbangan yang halus dan dinamis, reviewer Suatino, (ttp.), h 1-4

${ }^{27}$ Peneliti, Wawancara, Kayen, 12 Mei 2020

${ }^{28}$ Mohammad Zainal, Gilang Prakoso. "Analisis Pengaruh Sikap, Kontrol, Prilaku, Dan Norma Subjektif Terhadap Prilaku Safety”,( jurnal promkes, Vol 5 No 2, Desember 2017), h. 197
} 
apabila mereka memakai masker misalkan akan terhindar dari virus. Yang sebenarnya variabelnya banyak yang menyebabkan terkena virus, tidak hanya dari satu sisi saja. Dimasa new normal banyak orang-orang diluar sana tidak memakai masker tapi masih tetap sehat.

New normal merupakan kembali dengan keadaan yang normal. Yang sebenarnya masing dalam transisi dimana pandemi covid-19 ini kita mencoba untuk kembali baru tapi tidak meninggalkan protokol kesehatan sehingga kita harus tetap pakai masker, sering cuci tangan, physical distancing, jaga jarak jadi tetap mematuhi protokol kesehatan. ${ }^{29}$

Menurut ibu Sri Mujiati bertugas di Polindes Desa Kayen, "Dimasa new normal sekarang ini di desa Kayen termasuk kedalam zona putih, keterlibatan desa juga dari tokoh-tokoh masyarakat desa Kayen yang mana secara aktif untuk melakukan sosialisasi sehingga desa Sendang zona putih. Kemudian dari desa ada pembagian masker, penyemprotan keliling desinfektan, pembagian alat cuci tangan per-RT", meminjam alat termogan per-RW. ${ }^{30}$ Dikuatkan oleh bapak Kepala Desa Kayen bahwa warga Desa Sendang tidak ada yang terkena virus corona. ${ }^{31}$

Meskipun tidak ada yang terkena virus corona terkadang ada juga yang tidak memakai masker ketika keluar rumah, seperti ke sawah, dan kebun serta menjaga jarak. Namun tidak semua tidak menggunakan masker dan menjaga jarak. Contohnya ketika ada pengajian rutinan dan acara musyawarah desa warganya tetap memakai masker dan menjaga jarak. $^{32}$

\section{Analisis Pemanfaatan Sufi Healing di Desa Kayen}

Dalam suatu lingkungan masyarakat terdapat aktifitas-aktifitas yang biasanya menjadi rutinitas sehari-hari. Masyarakat yang melakukan aktifitas tersebut setiap harinya, seperti sholat baik sholat sunnah atau wajib, sholawatan, membaca al-Quran. Sesuai dengan penuturan ibu sulistiyani bahwa di desa Kayen khususnya Rt. 05 Rw. 02 pada setiap malam jum'at ada rutinan sholat sunnah mutla' dan setelah sholat sunnah mutlak ada pembacaan surah yasin dan dzikir-dzikir lainnya. Selain itu juga ada rutinan yasinan setiap malam jum'at juga yang dilakukan oleh bapak-bapak. Tak jarang juga ada pembacaan kalimah toyyibab/tablil untuk mendoakan keluarga yang telah meninggal.

Selain aktivitas-aktivitas ibadah di atas ada juga rutinan lain yang dilakukan oleh ibu-ibu seperti pembacaan manaqib Syekh Abdul Qodir

\footnotetext{
${ }^{29}$ Sri Mujiati, Wawancara, Kayen, 8 April 2020

${ }^{30}$ Ibid, Sri Mujiati

${ }^{31}$ Hasanudin, Wawancara, Kayen, 3 Mei 2020

32 Peneliti, Observasi, Kayen, 10 Mei 2020
} 
Al-Jailani. Kegiatan tersebut dilakukan setiap hari senin malam selasa. Tidak hanya itu saja ibu-ibu juga melakukan rutinan lain juga yaitu Khataman Al-Quran dilakukan setiap satu bulan sekali dan dilakukan bergiliran setiap orang yang mengikuti khataman tersebut. Khataman juga dilakukan oleh anak-anak kecil dan para remaja dilakukan setiap hari minggu akan tetapi semenjak adanya pandemi virus corona serta pembelajaran dilakukan secara daring sehingga kegiatan khataman tersebut menjadi hari jum'at. Ada juga pembacaan maulid al-diba'iyah wa al-barjanji yang dibacakan setiap malam selasa juga oleh santri dari pondok pesantren ada juga pembacaan maulid al-diba'iyah wa al-barjanji.

Para sufi memmulai dengan tahapan permulaan (al-bidayah) ada takholli, ada tahalli, ada tajalli dengan riyadhoh dan mijahadah. Tetapi untuk orang awam mungkin bisa melakukan aktivitas ibadah yang biasa dilakukan. Contoh-contoh dari aktivitas ibadah diatas juga mencerminkan bahwasannya adanya hubungan vertical antara hamba dengan tuhannya yang berdampak pada diri seseorang seperti kedekatan dia dengan tuhan dan berdampak pada meningkatnya iman dan ketakwaan seseorang. Dengan meningkatnya iman dan ketakwaan seseorang akan membuat batin seseorang merasa tenang.

Dikutip dari Khairunnas Rajab dalam jurnal mengatakan:

"In Islamic Sufism, the approaches of takhalliyya al-nafs, tahalliyy al nafs, and tajalliya al-nafs are preventive, medicinal, contructive methods and methods rehabilitation. They are method of Islamic psychotheraphy in curing the mental disorder. Islamic teachongs, such as faith, ritual, piety, good deed, and Islamic Sufism, are methodology of Islamic psychotheraphy to improve the mental health. Some aspects found in faith, ritual, and islamic Sufism, are base on the Islamic concepts which are suitable for curing the mental disorder, if those concepts are implemented, immoral acts can be avoided. As a result, the implementation of those conceptswill create optimism, strength, self confidence, honesty, and fairness". ${ }^{33}$

Dalam dunia tasawuf islam, pendekatan takhalliyya al-nafs, tahalliyya al-nafs dan tajalliyya al-nafs adalah metode pencegahan, pengobatan, metode konstruktif dan metode rehabilitasi. Mereka adalah metode psikoterapi islam dipenyembuhan gangguan mental. Ajaran islam, seperti keimanan, ritual, taqwa, perbuatan baik, dan tasawuf islam, adalah metodologi psokoterapi islam untuk meningkatkan kesehatan mental. Beberapa aspek ditemukan dalam iman, ritual, dan tasawuf islam,

33 Khairunnas Rajab, "Methodology of Islamic Psychotherapy in Islamic Boarding School Suryalaya (Tasik Malaya”, IJMS, Vol 4 No 2, December 2014), h. 262 
didasarkan pada konsep-konsep islam yang cocok untuk penyembuhan gangguan mental. Jika konsep tersebut diterapkan tindakan tidak bermoral bisa dihindari. Penerapan konsep tersebut akan menciptakan optimesme, kekuatan, kepercayaan diri, kejujuran dan keadailan.

Keimanan dan ketakwaan yang menimbulkan rasa ketenangan dalam diri sesorang. Menurut Herbert Bensen, ketenangan perasaan dan kejernihan fikiran disebutnya dengan istilah respons relaksasi. Contoh aktivitas yang memeunculkan respon relaksasi adalah dzikir, sholat, meditasi. Herbert juga mengemukakan bahwa respon relaksasi bukanlah hal yang baru dalam dunia kedokteran. Orang-orang arif pada zaman dahulu telah menggunakan praktik tersebut dalam pencegahan ataupun penyembuhan.

Repon relaksasi juga mempengaruhi kebutuhan oksigen dalam tubuh, karena bekerja dengan ringan. Metabolisme juga berkurang, pertukaran antara komponen-komponen yang berlangsung dalam suasana tanpa keterpaksaan, sehingga stress akan berkurang bahkan hilang dan gelombang boutak akan masuk dalam keadaan alfa dan bisa masuk kedalam keadaan delta yang membuat seseorang mengalami penyembuhan. Jadi keadaan yang relaks akan membuat seseorang itu pada kondisi sehat (homeostasis). ${ }^{34}$

Keadaan relaks tersebut yang dialami seseorang akibat dari prilakuprilaku atau aktivitas-aktivitas ibadah yang dilakukan akan berpengaruh juga pada imunitas tubuh terhadap berbagai serang penyakit, virus, dan patogen lainnya. Prilaku-prilaku tersebut dapat meningkatkan imunitas tubuh, karena kondisi sehat pada diri seseorang dipengaruhi oleh keseimbangan produksi hormonal dan kelenjar di tubuh. Oleh sebab itu aktivitas-aktivitas tersebut membuat cara berfikir yang positif dan berprilaku baik. ${ }^{35}$

Jadi jika dikaitkan dengan pandemi Covid-19 sekarang ini prilakuprilaku atau aktivitas ibadah yang diadaptasi dari praktik-praktik tasawuf baik untuk dilakukan untuk menjaga tubuh agar tetap dalam kondisi sehat (homeostasis). Selain itu juga untuk menjaga kesehatannya dengan minum vitamin atau multivitamin, yang terjangkau dengan minum vitamin $\mathrm{C}$ dan melakukan olah fisik pada umumnya yang bisa dilakukan.

\section{Kesimpulan}

\footnotetext{
${ }^{34}$ Taufik Pasiak,. Revolusi IQ/EQ/SQ: Menyingkap Rahasia Kecerdasan Berdasarkan Alquran dan Neurosains Mutakbir, (Bandung: PT.Mizan Pustaka, 2002), h. 230-232

35 Abdul Muhaya,. Pola Hubungan Antara Tasawuf dan Psikoneuroimunologi, laporan hasil Penelitian IAIN Walisongo (Semarang, 2006), h. 79
} 
Berdasarkan uraian di atas dapat disimpulkan bahwa aktivitasaktiivitas ibadah masyarakat Kayen Bandarkedungmulyo Jombang yang diadaptasi dari praktik-pratik tasawuf, pada masa new normal pandemi Covid-19, seperti membaca Alquran, Dzikir, Sholat, membaca sholawat yang menimbulkan ketenangan, bertambahnya iman dan ketakwaan seseorang sehingga bisa memunculkan respons relaksasi yang berdampak pada meningkatnya imunitas tubuh. Dengan meningkatnya imunitas tubuh seseorang membuat orang terhindar dari penyakit, virus, bakteri, atau pathogen lainnya, sehingga seseorang dapat menjaga kondisi tubuhnya sehat (homeostasis). Walaupun untuk penyembuhan butuh keistiqomahan dalam melakukan praktik-praktik ibadah yang dilakukan oleh seseorang. 


\section{Daftar Pustaka}

Al-Ghozali. Rabasia Ilmu Nafi': Kilas Balik Menuju Ilmu Nafi', alih bahasa Abu Fahdinal Husna dari judul asli Ayyuhal Walad, Jombang: Daru-Hikmah.

Ali-shah, Omar. Tasawnf Sebagai Terapi, Bandung: Pustaka Hidayah, 2002. Dodi, Limas, "Nilai Spiritualitas Sayyed Hossein Nasr dalam Manajemen Pendidikan Islam", Diräsät: Jurnal Manajemen dan Pendidikan Islam, Vol 4, no. 12018.

, "Antara Spiritualitas dan Realitas Tarekat Shiddiqiyyah dalam Bingkai Fenomenologi Annemarie Schimmel”, Prosiding Nasional Pascasarjana LAIN Kediri, Vol 12018.

Farhan, Ibnu. "Konsep Maqamat Dan Ahwal Prespektif Para Sufi", YAQZHAN, Vol 2 No 2, Desember 2016. Annemarie Schimmel https://www.kemkes.go.id, diakses 29 Agustus 2020.

Jaenudin, Ujam. Psikologi Transpersonal, Bandung: CV. Pustaka Setia, 2012. Junaidi, Mahbub. "Manusia Dalam Berbagai Perspektif', Dar el-Ilmi: jurnal studi agama, pendidikan dan bumaniora, Vol 4 No 1, April 2017.

Mohammad Zainal, Gilang Prakoso. "Analisis Pengaruh Sikap, Kontrol, Prilaku, Dan Norma Subjektif Terhadap Prilaku Safety”, jurnal promkes, Vol 5 No 2, Desember 2017.

Muhaya, Abdul. Pola Hubungan Antara Tasawuf dan Psikoneuroimunologi, laporan hasil Penelitian IAIN Walisongo Semarang, 2006.

Mujayatun. Wawancara, Kayen, 5 Agustus 2020.

Mujiati, Sri. Wawancara, Kayen, 8 Agustus 2020.

------. Wawancara, Kayen, 8 Agustus 2020.

Monty, Satiadarma. Terapi Musik, Jakarta: melenia popular, 2002.

Nata, Abuddin. AKHLAK TAS AWUF, Jakarta: PT RAJA GRAFINDO PERSADA, 2012.

Ni'am, Syamudin. Tasawuf Studies: Pengantar Belajar Tasawnf, Yogyakarta: Ar-ruz Media, 2014.

O'riordan, Linda. Seni Penyembuban Alami: Rabasia Penyembuban Melalui Energi Ilahi, penerjemah Sulaiman al-Kumayi, Jakarta: Gugus press, 2002.

Sulaiman. Sufi Healing: Penyembuhan Penyakit Labiriah dan Batiniah, Semarang: karya abadi jaya, 2015.

Pasiak, Taufik. REVOLUSI IQ/EQ/SQ: Menyingkap Rahasia Kecerdasan Berdasarkan Alquran dan Neurosains Mutakhir, Bandung: PT.Mizan Pustaka, 2002.

Penulis. Observasi, Kayen, 17 juli 2020.

Rahman, Farhat Naz. "spiritual healing and sufi practices", nova journal of sufism and spirituality, Vol, 2 No. 1, 2014. 
Rajab, Khairunnas. "Methodology of Islamic Psychotherapy in Islamic Boarding School Suryalaya Tasik Malaya", IJMS, Vol 4 No 2, December 2014.

Rayani Hanum, Bangun Nasution. Akblak Tasawnf, Jakarta: Rajawali pers, 2003.

Schimmel, Anniemarie. Dimensi Mistik Dalam Islam, penerjemah: Sapardi Djoko Damono dari judul asli Mystical of Islam, Jakarta: Pustaka firdaus, 2003

Sentot, Haryanto. Psikologi Sholat Kajian Aspek-Aspek Psikologis Ibadah Shalat, Yogyakarta: Mitra Pustaka, 2005.

Sholihin, M. Terapi Sufistik, Bandung: pustaka setia, 2004.

Siagian, Minarma. HOMEOSTASIS: keseimbangan yang halus dan dinamis, reviewer Suatino

Amin dan Sutarmo Setiadji, Departemen ilmu Faal FKUI, ttp.

Suhadi, Ahmad. Wawancara, Kayen, 21 Juli 2020.

Sulistiyani. Wawancara, Kayen, 4 Agustus 2020.

Susilo, Adityo, dkk. "Corona Virus Diseases (COVID-19): tinjauan literatur terkini Corona Virus Diseases 2019: review of current literatures", jurnal penyakit dalam Indonesia, Vol 7 No 1, Maret 2020.

Syukur, Amin. Sufi Healing Terapi Dengan Metode Tasawuf, Jakarta: Erlangga, 2012.

. "Sufi Healing: Terapi Dalam Literature Tasawuf", Walisongo, Vol 20 No 2, November 2012.

Yuliana. Corona Virus Diseases (COVID-19): sebuah tinjanan literatur. wellness and healthy magazine, 2020. 